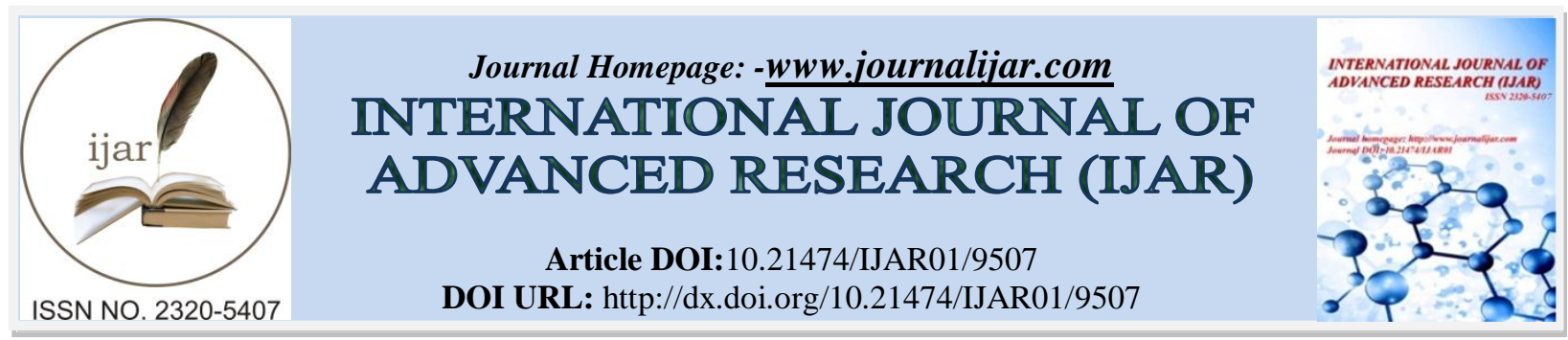

RESEARCH ARTICLE

\title{
ASSITENCE ON THE USE OF SOUND WAVE ATTRACTOR TO INCREASE FISHERMEN'S NUMBER OF CATCHES BULAK DISTRICT SURABAYA.
}

Nurul Rosana ${ }^{1}$, Ma Sofijanto ${ }^{1}$ and Suryadhi ${ }^{2}$.

1. Hang tuah university fisheries study program.

2. Hang tuah university electrical engineering study program.

\section{Manuscript Info}

Manuscript History

Received: 06 June 2019

Final Accepted: 08 July 2019

Published: August 2019

Key words:-

Attractor, sound wave, gill net.

\begin{abstract}
The Gillnet Fisheries Group Partnership Program in the Bulak District of Surabaya is one of the Community Service activities which carried out by Hang Tuah University in collaboration with the Research and Technology Ministry and the Indonesian Traditional Fishermen Group. The activity carried out is to provide a solution by assisting the use of sound wave based fish calling equipment as fishing aid to gill nets so that fishing operations are expected to be more efficient and the number of catches will increase. The method used in this partnership program is to provide assistance to gill net fishermen groups in the Bulak District of Surabaya. The activity was held on Friday, June 14, 2019 and was attended by 15 gill net fishermen. The tool socialized for its use in the mentoring program is a sound wave based fish calling device which has a frequency between 500-1000 Hz. Implementation of assistance to gill nets fishermen using sound wave based attractors is expected to be a solution in the sustainability of gill net fishing gear in the future by applying appropriate technology.
\end{abstract}

Copy Right, IJAR, 2019,. All rights reserved.

\section{Introduction:-}

Gillnet is a type of rectangular fishing gear equipped with a float, sinker, upper rope and bottom rope or no lower riser to block fish so that the fish is caught by being entangled and / or thickened, and is operated in surface, middle and bottom permanently, swept away and circular with the aim of catching pelagic and demersal fish (PER.08MEN-2008, 2008).

Gillnets are operated by many fishermen in the Bulak Sub-district of Surabaya. Gillnet, including a simple and passive fishing gear, because it is installed in the waters waiting for the fish to approach the net and get entangled. The use of gill net fishing gear is one of the livelihoods carried out by means of a one day system operation that is conducting fishing operations in one day at sea without staying overnight at sea. The fishing fleet used is a 5 GT motor boat and uses a fishing gear net with a length of 25 meters and a width of 7 meters. Fishing operations are usually carried out for approximately 3-4 hours in the morning starting at 6:00 a.m. Compared with the number of catches by using other fishing gear that are relatively larger, it is necessary to improve efforts to catch catches with the application of appropriate and easy to apply technology.

Corresponding Author:-Nurul Rosana.

Address:-Hang tuah university fisheries study program. 
The priority issues of gillnet fishermen groups are (1) the passive way of catching gillnet fishing gear and waiting time for fish to come to gillnet is around 3-4 hours, so that the amount of catches obtained has not been proportional to the efforts made or not maximal, (2) the insight and skills of gillnet fishermen are still lacking in applying appropriate technology-based fishing aids that can increase catches.

The Gillnet Fisheries Group Partnership Program in the Bulak District of Surabaya is one of the Community Service activities carried out by Hang Tuah University in collaboration with the Research and Technology Ministry and the Indonesian Traditional Fishermen Group. The theme of this community service activity is "The Use of Sound Wave Based Attractor on Gillnets to Increase the Number of Catches". The priority issue of gill nets fishing groups in community service locations is passive fishing operations and the waiting time for fish to come to the nets is relatively long, so the number of catch is not comparable to the efforts made. The insight and skills of gill net fishermen are felt to be lacking in applying appropriate technology-based attractors.

\section{Research Purpose:-}

The purpose of the activity carried out is to provide a solution by assisting the use of sound wave based fish calling equipment as fishing aid for gill nets so that fishing operations are expected to be more efficient and the number of catches will increase.

\section{Research Methods:-}

The method used in this partnership program is to provide assistance to gill net fishermen groups in the Bulak District of Surabaya. The activity was held on Friday, June 14, 2019 and was attended by 15 gill net fishermen. At the time of mentoring, each fisherman was given a sound wave based attractor and explained how to operate it. The attractors used can be seen in Figure 1.

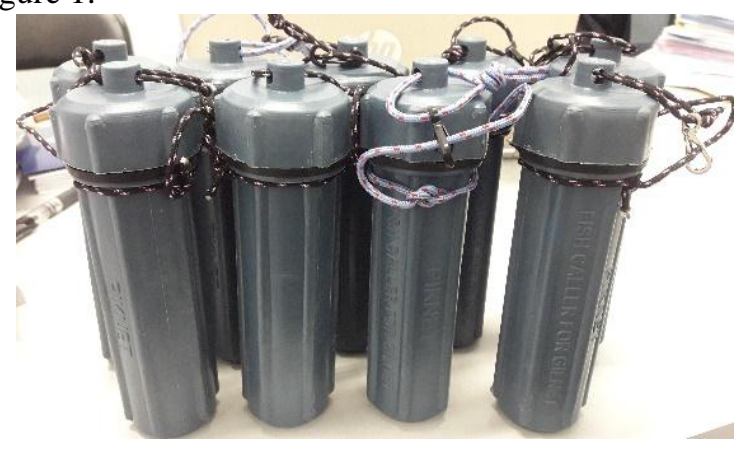

Figure 1:-Sound Wave Based Attractor

The tool socialized for its use in the mentoring program is a sound wave based fish caller device which has a frequency between 500-1000 Hz. The tool used is the output from the Research and Technology Ministry's Applied Research Grant. Sound wave based fish caller devices have been tested in the early stages in the laboratory by using sea water aquariums and in the wave range of 500-1000 Hz (N Rosana, Suryadhi and SafriudinRifandi. 2108). This tool has also been tested in waters using gill nets and shows significant results seen from the acquisition of higher catches (Rosana, N. and Rifandi, S, 2018).

\section{Research Result And Discussion:-}

Assistance which carried out to gill nets in the Bulak District of Surabaya City is an insight to the development of gill nets, by comparing the use of the similar tool in other places. At the time of assistance, fishermen were active in discussions so that there was a new understanding of the use and latest technological developments that could be applied to fishing operations using gill nets. Implementation of assistance to gill net fishermen discusses problems regarding the development of gill nets going forward, which are expected to be sustainable and sustainable by applying appropriate technology (figure 2) 


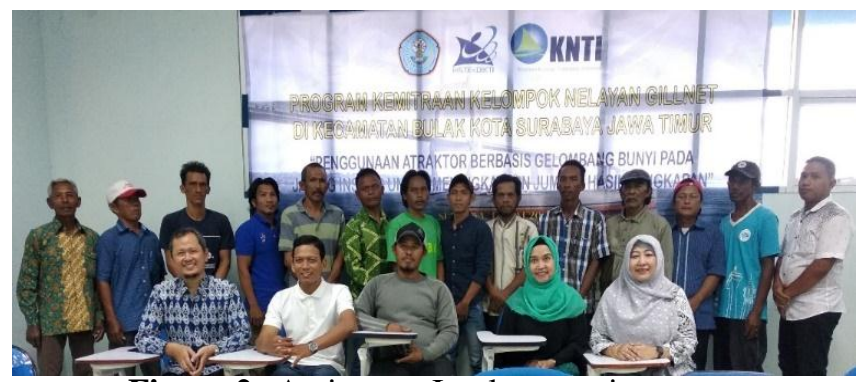

Figure 2:-Assistance Implementation

How to work using a sound wave based attractor is very easy principally. The attractor is mounted on the gill net by fastening it to the upper rope section because the device can be securely attached to the stretched position. The tool will work after being connected to the battery. The instrument will make a sound starting from the frequency of 500$1000 \mathrm{~Hz}$ with 3 repetitions on each frequency repeatedly (figure 3).

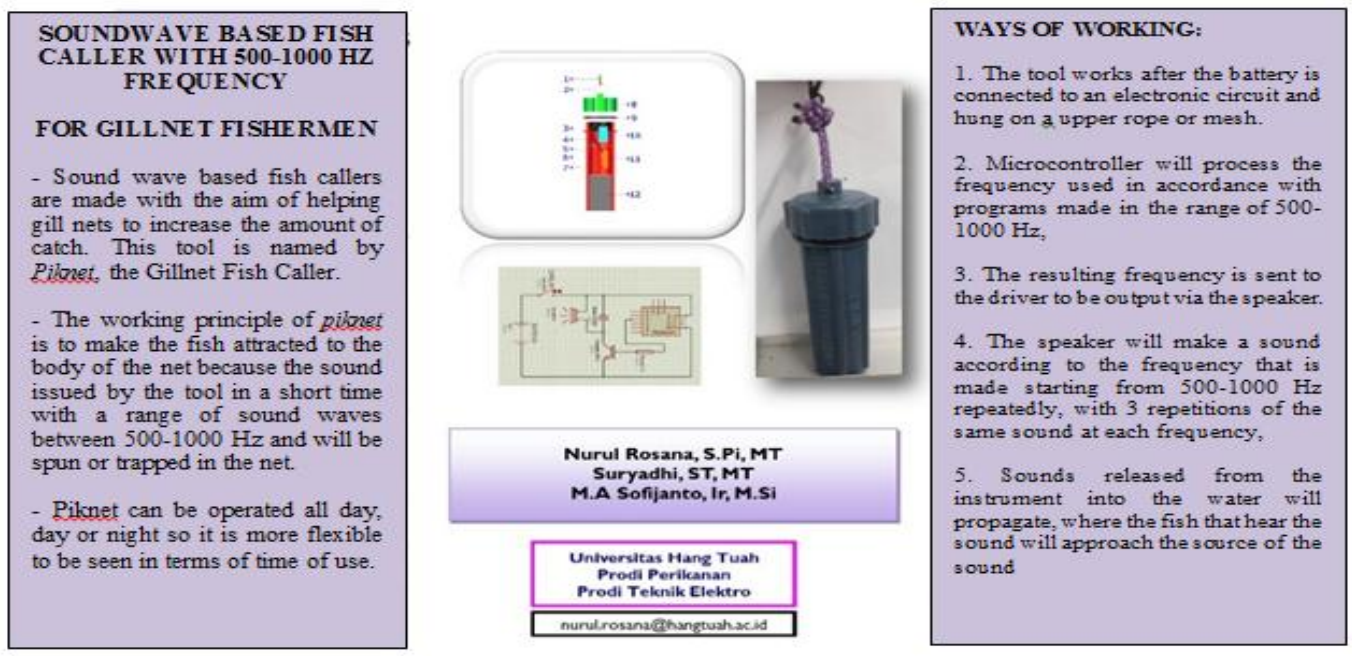

Figure 3:-Attractor Profile and Working Ways

If it's examined from the time spent on fishing operations using the gill nets at this time, the hope of fishermen with the use of soundwave based attractor can increase number of catches and shorten the time of catching operations. Fishermen's expectation besides increasing the number of catches is the possibility of changes in the distance of the fishing area can change closer to the distance because the fish are lured by the sound produced by the tool, so that it approaches the gill net and is entangled (N Rosana and Suryadhi, 2017). Some types of fish caught by gill nets are pelagic and demersal fish species, including peanut fish (Oxyporhamphusmicropterus), gulamah (Pseudocienaamoyensis), white snapper (Latescalcalifer), chicken feathers (Thryssasetirostris), laosan (Eleutheronematetradactylum), white snapper (Latescalcalifer), milkfish (Chanoschanos) and cork (Glossolepisincisus).

Stages of evaluating the performance of tools in waters are carried out by conducting interviews with fishermen as tool users (Figure 4). Some of the factors used in evaluating the use of contractors include:easy of use when operating in waters, changes in the amount of catches obtained, types of fish caught, desire to use sound wave based attractor, suitability of the fishing gear used, and suggestions for the development of sound wave based attractor. It is expected that in the evaluation phase it will be able to produce suggestions and suggestions for the improvement of the equipment, so that it can be revised and modified according to its use in waters. 


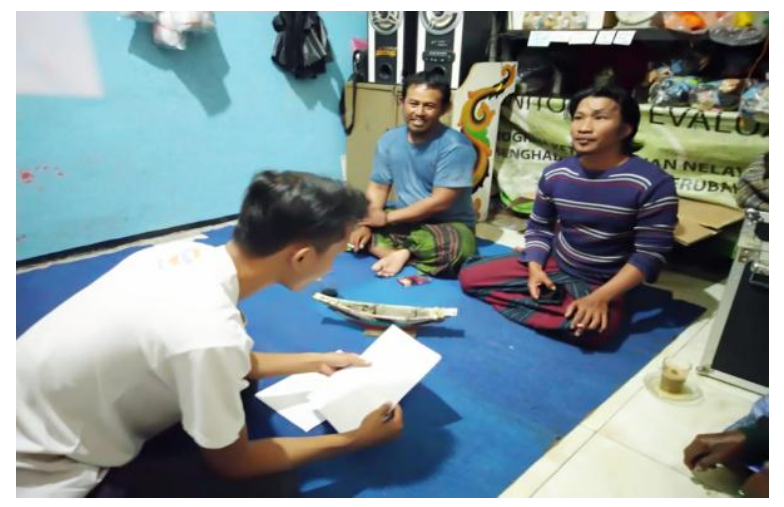

Figure 4:-The Process of Evaluating the Use of Sound Wave Based Attractors

\section{Conclusions And Recommendations:-}

Implementation of assistance to gill net fishermen using sound wave-based attractors is expected to be a solution in the sustainability of gill net fishing gear in the future by applying appropriate technology according to the conditions of gill nets.

\section{Bibliography:-}

1. N RosanadanSuryadhi. 2017. PenentuanGelombangBunyiDalamPembuatanAlatPemanggillkan "Piknet" Prosiding Seminar Nasional Kelautan XII Universitas Hang Tuah. Surabaya.

2. N Rosana, Suryadhi and SafriudinRifandi. 2108. Trial Test of Fish Attractor "Piknet" Device in Saltwater Fish Tank. MATEC Web of Conferences 177, 01021 (2018) https://doi.org/10.1051/matecconf/201817701021.

3. Rosana, N. and Rifandi, S. 2018. RancangBangun Dan UjiCobaAlatPemanggillkan "Piknet" UntukAlatTangkapJaringInsang. Marine Fisheries: Journal of Marine Fisheries Technology and Management, 9(2), pp.199-207.

4. PeraturanMenteriKelautanDan P erikananRepublikIndonesia

NomorPer.08/Men/2008 TentangPenggunaanAlatPenangkapanIkanJaringInsang(GillNet) DiZonaEkonomiEksklusifIndonesia $\begin{array}{lcccr}\text { [Internet]. } & \text { [Diunduh } & 2016 & \text { April } & \text { 5]. } \\ \text { http://www.itjen.kkp.go.id/pustaka/images/stories/pdf/PER.08-MEN-2008.pdf. }\end{array}$ 